\title{
GYMNASIETS GENETIK - SVÅRT ELLER BARA ETT DIDAKTISKT PROBLEM?
}

\author{
Irmeli Palmberg ${ }^{1}$, Johanna Björk², Kristoffer Kronlund², Mecki Lindén², Marina \\ Sandkvist $^{2} \&$ Sara Sandström ${ }^{2}$
}

\author{
${ }^{1}$ Akademilektor i biologins och geografins didaktik, Pedagogiska fakulteten, Åbo Akademi \\ Strandgatan 2, 65100 Vasa, irmeli.palmberg@abo.fi \\ 2 Ämneslärarstuderande i biologi och geografi, Pedagogiska fakulteten, Åbo Akademi
}

\begin{abstract}
According to previous research, pupils and students regard genetics as a very difficult subject. They find it abstract, and the use of many concepts at several different levels in the same textbook makes it difficult for them to understand. Teaching methods and ways of working have been criticised as part of the problem. The aim of this study is to summarise previous research on pupils' knowledge of genetics and on teaching methods in genetics, to analyse curricula and textbooks in school genetics, and to test a group of Finland-Swedish secondary-school students' understanding of the basic concepts and processes in genetics, and their opinion about genetics. The test of concepts was carried out as a multiple-choice test, completed by an open question concerning the best way(s) to learn genetics as judged by the students. The results indicated that the majority of students did not regard either genetics or the textbook as difficult; yet they lacked their own unquestionable knowledge about basic concepts and processes. There was no correlation between the test results and the way(s) the students experienced genetics, neither between the test results and the way(s) in which the students felt that they learned genetics best. More than half of the students emphasised the role of the teacher, i.e. lecturing, as the best way to learn genetics. The need and alternative ways to develop the teaching of genetics are discussed.
\end{abstract}

Keywords: attitudes to genetics, concept knowledge, misconceptions, teaching methods

\begin{abstract}
Abstrakt Enligt tidigare forskning uppfattas genetiken som ett speciellt svårt ämne av elever och studerande. Ämnet upplevs som abstrakt och användningen av ett stort antal begrepp på flera olika nivåer i en och samma lärobok försvårar förståelsen ytterligare. Undervisningsmetoderna och arbetssätten har kritiserats som en del av problemet. Syftet med detta arbete är att sammanfatta tidigare forskning om elevers kunskaper i genetik och om undervisningsmetoder i genetik, analysera läroplaner och skolböcker samt testa en grupp finlandssvenska gymnasiestuderandes begreppskunskap i och åsikt om genetik. Begreppstestet utfördes som flervalsfrågor och kompletterades med en öppen fråga om de bästa sätten att lära sig genetik. Resultaten visar att majoriteten av gymnasiestuderande inte upplever ämnet genetik eller läroboken i genetik som svåra, men att de trots det saknar säker kunskap om grundläggande begrepp och processer inom ämnet. Det fanns inget samband mellan testresultat och huruvida de studerande upplever genetiken som lätt eller medelsvårt, inte heller mellan testresultat och sätten att lära sig genetik. Över hälften av de studerande betonade lärarens roll och därmed framställande undervisning som det bästa sättet att lära sig genetik. Behov och möjligheter att utveckla genetikundervisningen diskuteras.
\end{abstract}

Nyckelord: attityder till genetik, begreppskunskap, missuppfattningar, undervisningsmetoder 


\section{GYMNASIETS GENETIK -
SVÅRT ELLER BARA ETT DIDAKTISKT PROBLEM?}

\section{$1 \quad$ Inledning}

Goda grundläggande kunskaper i genetik har fătt allt större betydelse i samhället i och med att användningen av nya genteknologiska tillämpningar ökat inom många områden. Ett område är t.ex. hälsovården, där det krävs vetenskaplig förståelse av genetiska processer som en förutsättning för en säker diagnostisering och behandling av ett stort antal sjukdomar (Spradling, Ganetsky, Hieter, Johnston, Olson, Orr-Weaver, Rossant, Sanchez \& Waterson, 2006). Dessutom behöver vissa yrkesgrupper genetikkunskap för att kunna förstå hur hälsan i allmänhet påverkas av växelverkan mellan de biologiska, sociala, beteendemässiga, kulturella, ekonomiska och ekologiska faktorerna. För såväl elever som övriga medborgare är det svårt att utan grundläggande förståelse i genetik ta ställning till aktuella frågor, såsom genmodifierad mat och genmodifierade organismer (Aldahmash \& Alshava, 2012). En grundläggande referensram med de genetiska begrepp och mekanismer som är involverade i organismernas evolution skulle hjälpa dem att även förstå den biologiska betydelsen av olika fenomen, såsom celldelning och fortplantning (Banet \& Ayuso, 2003; Chattopadhyay, 2005; Lewis \& Kattman, 2004; Lewis, Leach \& WoodRobinson, 2000).

Enligt tidigare forskning uppfattar elever på såväl skol- som universitetsnivå genetiken som ett speciellt svårt ämne (t.ex. Chattopadhyay, 2005; Chu \& Reid, 2012; Gericke \& Hagberg, 2007; Kibuka-Sebitosi, 2007; Lewis \& Kattmann, 2004; Rotbain, Marbach-Ad \& Stavy, 2006; Tsui \& Treagust, 2010). Orsakerna rapporteras vara många, t.ex. att ämnet är abstrakt och begreppen förekommer samtidigt på flera olika nivåer. Detta överbelastar bl.a. hjärnans arbetskapacitet (Chu \& Reid, 2012) och ämnet upplevs därför som svårbegripligt. En del forskning antyder att själva undervisningen, d.v.s. undervisningsmetoderna, är orsaken till problemet (Baker \& Lawson, 2001; Johnson \& Stewart, 2002; Rotbain m.fl., 2006; Templin \& Fetters, 2002a, b). En grundläggande brist i undervisningen är att eleverna inte uppmuntras att konfrontera konflikter eller paradoxer som uppstår mellan deras egen uppfattning och den nya kunskap som lärs ut. Istället konstruerar de svaga eller felaktiga modeller om fenomenet i fråga (Mintzes, Wandersee \& Novak, 2002). Flera studier har även visat att lärarnas egna missuppfattningar starkt påverkar eleverna (Dikmenli, 2010; Yip, 1998). Som ytterligare orsaker till att genetik upplevs som ett svårt ämne lyfter andra fram brister i läroböcker (Aivelo \& Uitto, 2014; Flodin, 2009; Gericke, 2009; Gericke \& Hagberg, 2010a, b; Gericke, Hagberg, dos Santos, Joaquim \& El-Hani, 2012; dos Santos, Joaquim \& El-Hani, 2012), eller oklarheter i själva kunskapsinnehållet, eftersom det saknas en helhetsbild om vad som verkligen undervisas eller borde undervisas (Elmesky, 2013; Flodin, 2009). Den snabba utvecklingen inom genetik, genteknologi och bioteknik bidrar dessutom till ytterligare begrepp, förklaringar av genetiska processer och tillämpningsmöjligheter, vilka inte i första hand når skolgenetiken. 


\section{Syfte och forskningsfrågor}

Syftet med detta arbete är att först analysera läroplaner och skolböcker angående genetikundervisningen, sedan analysera och sammanfatta tidigare forskning om elevers kunskaper om de grundläggande begreppen i genetik och vilka undervisningsmetoder som använts, och till sist undersöka gymnasiestuderandes grundläggande begreppskunskaper i genetik och inställning till genetikundervisning i en finlandssvensk skola. Arbetet, som har utförts som en del av de ämnesdidaktiska seminarierna i biologi och geografi inom ämneslärarutbildningen vid Åbo Akademi, är även tänkt som underlag för lärare för att de i sin undervisning bättre kunde beakta missuppfattningar samt välja undervisningsmetoder och arbetssätt som gynnar elevers lärande i genetik.

För att uppnå syftet har följande forskningsfrågor utformats:

1. Vad bestäms om genetikundervisningen i grundskolans och gymnasiets läroplaner?

2. Hur presenterar skolböckerna grundbegrepp och processer i genetik?

3. Hur förstår en grupp gymnasiestuderande grundläggande begrepp och processer i genetik?

(Med denna fråga vill vi undersöka om gymnasiestuderande har förstått innebörden i begreppen DNA, gen, kromosom, förhållandet mellan gen och egenskap, förhållandet mellan genotyp och fenotyp samt processerna mitos och meios.)

4. Vad anser gymnasiestuderande om genetik som skolämne?

(Eftersom tidigare forskning visar att många upplever skolgenetiken som svår, vill vi fråga de studerande om deras uppfattning om svårighetsgraden i genetik, men också i de aktuella läroböckerna. Dessutom analyserar vi huruvida deras inställning till genetik avspeglas i testresultaten.)

5. Hur anser gymnasiestuderande att de lär sig genetik bäst?

(Med denna fråga vill vi reda ut om de som gymnasiestuderande redan identifierat hur de bäst lär sig genetik och om de upptäckt speciella sätt att lära sig, men också hur de nämnda sätten avspeglas i testresultaten.)

\section{Material och metoder}

Fyra läroplaner analyserades för att få fram stadie- och utvecklingsskillnader i genetikundervisningen. För grundskolans del granskades innehållet i Grunderna för läroplanen för den grundläggande utbildningen 2004 (härefter GLGU, 2004), medan gymnasiegenetiken granskades från Grunderna för gymnasiets läroplan 1985 (GGL, 1985), 1994 (GGL, 1994) och 2003 (GGL, 2003). Grundbegrepp och grundprocesser i genetik analyserades i tre aktuella skolböcker: Skolans biologi, Människan (för årskurs 9), Skolans biologi, Cellen och ärftligheten (en obligatorisk gymnasiekurs) och Bios 2, Cellen och ärftligheten (ett annat alternativ för den obligatoriska gymnasiekursen). En systematisk litteratursökning på 12 internationella tidskrifter utfördes för att få fram tidigare forskning om elevers kunskaper och missuppfattningar i genetik samt om olika undervisningsmetoder inom genetik. 


\section{GYMNASIETS GENETIK - SVÅRT ELLER BARA ETT DIDAKTISKT PROBLEM?}

Totalt 46 gymnasiestuderande (31 kvinnor och 15 män, i åldern 16-18 år) från ett finlandssvenskt gymnasium deltog $\mathrm{i}$ en pilotstudie. Kriterierna vid urvalet var att de deltagande studerandena hade haft genetik i grundskolan, men också deltagit i minst en av de två obligatoriska biologikurserna i gymnasiet, varav huvudsakligen kurs 2 (Cellen och ärftligheten) behandlar genetik. Endast åtta av de 46 studerandena hade inte ännu deltagit i kurs 2 (men nog haft genetik på högstadiet), medan många av dem även hade deltagit $\mathrm{i}$ valbara biologikurser i gymnasiet (kurs 3: 17/46; kurs 4: 28/46; kurs 5: 9/46), varav kurs 5 (Bioteknologi) är en fördjupningskurs i genetik. Testet var frivilligt och det påpekades att undersökningen inte påverkar betyget i biologi.

Vi utarbetade en enkät med flervalsfrågor på basis av dels tidigare forskning (modifierade frågor från Rotbain, Marbach-Ad \& Stavy, 2005, 2006) och dels de aktuella läroböckerna för kurs 2. Förutom respondentens bakgrund (kön, ålder och avlagda biologikurser vid gymnasiet) frågade vi deras åsikt om genetik och om läroböckerna i genetik med en femgradig skala (från mycket lätt till mycket svårt). De sex kunskapsfrågorna bestod av fyra påståenden, varav ett alternativ var rätt (se senare i tabell 4). De felaktiga alternativen (distraktorerna) valde vi så att de var optimalt trovärdiga (bl.a. enligt alternativ som lockat i tidigare forskning). Dessutom frågade vi de studerande efter varje kunskapsfråga om de var säkra på sitt svar (ja/nej) för att ytterligare få fram om de ansåg sig kunna svaret eller bara hade gissat. Ett felaktigt svar, som studerande varit säker på att varit rätt, kan höra till de s.k. stabila missuppfattningarna, vilka är svåra att få bort (Flodin, 2009).

Vi presenterade syftet med undersökningen och gav instruktioner om att fylla i enkäten i början av en vanlig biologilektion, varefter vi delade ut enkäterna och påpekade att de studerande noggrant ska svara enligt sin nuvarande kunskap. Ifyllandet tog ca 20 minuter. Ett rätt svar bedömdes med en poäng. De studerande ombads dessutom beskriva hur de bäst lär sig genetik. Svaren i denna öppna fråga indelades i innehållsanalysen i sex kategorier och exempel på de olika kategorierna presenteras som direkta citat. En och samma studerande kunde nämna inlärningssätt från flera kategorier, varför citaten ges som helhet.

\section{Genetik i den finländska läroplanen}

Enligt den aktuella läroplanen för grundskolan (GLGU, 2004, s. 179-181) ska eleverna redan i årskurs 7-9 lära känna och kunna använda centrala begrepp med anknytning till ärftlighet. Som innehåll i temat "människan" ingår aspekter om människans biologiska evolution samt arvsmassans och miljöns betydelse för utvecklingen av människans egenskaper. Angående målen och innehållet i genetik för gymnasiets del har den snabba utvecklingen av molekylärbiologisk kunskap och genteknologi inte nått läroplanerna. Genetik förekom i två av de tre obligatoriska biologikurserna i läroplanen från år 1985 (GGL, 1985, s. 306-307). Den första kursen beskrev bl.a. DNA, RNA, proteinsyntes, mitos 
och meios, medan den andra kursen betonade inlärning av grundbegreppen i genetik, olika korsningsförsök, könskromosomers och mutationers roll samt arvsfaktorer i en population. Målet i läroplanen från 1994 var att eleverna skulle bli insatta "i det viktigaste av de genetiska reglermekanismer som styr livet och evolutionen både på cell- och individnivå samt i en population" (GGL, 1994, s. 88). Ingenting preciserades om t.ex. vad som åsyftas med det viktigaste. Endast den ena av de två obligatoriska kurserna behandlade genetik. Målet var dessutom att eleverna skulle "bli förtrogna med de mekanismer och lagbundenheter som styr genernas funktion och ärftlighet på cell-, individ- och populationsnivå". Därtill betonades "yttre faktorers inverkan på det genetiska informationssystemet och hur förändringar i genernas arvsmassa påverkar organismernas utveckling" samt "hur människans verksamhet påverkar genotypen och vilka risker detta medför" (GGL, 1994, s. 89). Inget närmare innehåll preciserades, inte heller hur denna undervisning skulle utföras.

Den senaste läroplanen (GGL 2003) har samma grundläggande mål och samma innehåll som de tidigare läroplanerna. Undervisningen ska med andra ord ge färdigheter för eleverna (som i denna läroplan kallas för studerande) att behärska de centrala begreppen inom biologin, men de ska även förstå arvsmassans och evolutionens betydelse för organismernas utveckling samt arvs- och miljöfaktorernas betydelse för hälsan både ur individens och ur mänsklighetens synvinkel. Undervisningen ska även skapa en grund för att kunna förstå de möjligheter som biovetenskaperna ger då det gäller att förbättra människosläktets, övriga organismers och ekosystemens välbefinnande. Den ena av de två obligatoriska kurserna har som mål att eleverna lär "känna till den genetiska informationsstrukturen och informationsöverföringen från cell till cell och generation till generation, veta hur generna styr cellens funktioner och kunna grundprinciperna för ärftlighetens lagbundenheter" (GGL, 2003, s. 133). Innehållet i kursen ska behandla DNAstrukturen och funktionen, proteinsyntesen, mitosen och dess betydelse, cellens delning, tillväxt och differentiering, gener och alleler, könsceller, ärftlighetsmekanismer och populationsgenetik. Sammanfattningsvis kan således konstateras att studerandena enligt läroplanen redan efter avslutad grundskola, men allra senast efter gymnasiets kurs 2, borde behärska de grundbegrepp och de grundläggande processer i genetik som vi testar i denna studie.

\section{Genetikbegrepp och -modeller i läroböcker}

En av orsakerna till varför genetik uppfattas som ett svårt ämnesområde kan ha sin förklaring i hur ämnet presenteras i de läroböcker som används i skolor. I flera studier har man på senare tid undersökt användningen av begreppet gen och genfunktion i läroböcker (Flodin, 2009; Gericke, 2009; Gericke \& Hagberg, 2010; Gericke m.fl., 2012; dos Santos m.fl., 2012). Dessa studier pekar alla på att begreppet gen, genmodeller och genernas funktion i levande system presenteras på ett inkonsekvent sätt, även inom en och samma lärobok. Gericke (2009) har identifierat fem modeller av genfunktion: mendelistisk, 


\section{GYMNASIETS GENETIK - SVÅRT ELLER BARA ETT DIDAKTISKT PROBLEM?}

klassisk, biokemisk-klassisk, neoklassisk och modern modell, och analyserat läroböcker på basis av dessa modeller (Gericke \& Hagberg, 2010). Gericke och hans medarbetare (2012) påpekar att trots att begreppet gen varierar och att olika modeller används, förklaras de inte i läroböcker. Modellerna är i själva verket historiskt uppbyggda för att beskriva gener och deras funktioner och begreppet gen varierar beroende på kontexten. De olika sätten att använda samma begrepp tros leda till missförstånd hos eleverna. Dos Santos och hennes medarbetare (2012) visar ytterligare att presentationen i läroböcker ofta leder till att eleverna skapar hybrida synsätt, vilka inte motsvarar de vetenskapliga modellerna utan istället är blandningar av dessa. Dessa synsätt skapar hos elever en deterministisk syn på gener, vilket i sin tur leder till missuppfattningar om genernas natur och deras roll i levande system, och därmed hindrar fortsatt inlärning.

Användningen av begreppet gen har nyligen undersökts i de aktuella finskspråkiga läroböckerna för gymnasiet, där även Gerickes modeller (2009) kunde identifieras, med undantag av den moderna modellen (Aivelo \& Uitto, 2014a, b). I de svenskspråkiga skolorna används motsvarande läroböcker som är översatta men även delvis modifierade. I det följande ger vi en kort översikt av vilka de grundläggande begreppen inom genetik är, och hur de för vår undersökning relevanta begreppen definieras och används i de svenskspråkiga skolböckerna. Boken Skolans biologi, Människan (Jortikka, Leinonen, Nyberg, Veistola \& Flemmig, 2013), som huvudsakligen är avsedd för grundskolans årskurs 8 eller 9, beskriver med text och bilder grundbegrepp och processer i genetik. Gen och arvsanlag används synonymt. En enkel förklaring ges om att generna styr individens utveckling. Varje gen styr, enligt boken, uppkomsten eller funktionen av någon ärftlig egenskap, men de flesta egenskaperna styrs av flera gener tillsammans. Ytterligare beskrivs DNA, kromosom, könskromosom, kromosomuppsättning, kromosomavvikelser, genotyp och fenotyp, homologa kromosomer, homozygot, heterozygot, dominanta och recessiva egenskaper. De enkla förklaringarna om nedärvningen är tänkta att underlätta förståelsen, men de kan tvärtom senare ligga som hinder för en djupare förståelse för de genetiska processerna.

I de svenskspråkiga gymnasierna används huvudsakligen två böcker för undervisning $\mathrm{i}$ genetik: Bios 2, Cellen och ärftligheten (Happonen, Holopainen, Sotkas, Tenhunen, Tihtarinen-Ulmanen \& Venäläinen, 2005) och Skolans biologi. Cellen och ärftligheten (Leinonen, Nyberg, Tast, Tyrväinen, Veistola \& Sandvik, 2006). Det finns brister och otydligheter i bägge. Bios 2 tar oftast upp alleler i stället för gener. I de första kapitlen beskrivs dessutom endast att generna påverkar egenskaper då de styr utvecklingen. Man får vänta ända till bokens sista kapitel för att få reda på att generna styr syntesen av enzymer, men inte ens där klargörs det tydligt på vilket sätt generna styr utvecklingen. Otydligheten i formuleringen och speciellt definitionen av begreppet gen kan vara en orsak till att eleverna har svårt att förstå förhållandet mellan gen och egenskap. Skolans biologi definierar klart en gen som en sekvens som styr bildandet av ett protein, vilket i sin tur påverkar 
utvecklingen av en ärftlig egenskap. Bios 2 däremot ger en mycket ytlig definition och beskriver endast att en gen styr cellens och organismens livsfunktioner, utan att precisera på vilket sätt detta sker (se närmare i tabell 1). I Skolans biologi behandlas grunderna i ärftlighet, celldelning och korsning före proteinsyntesen. Proteinsyntesen nämns också som en länk mellan gener och egenskaper, och att generna styr proteinsyntesen. Ordningen verkar logisk, och eftersom proteinsyntesen behandlas direkt efter generna torde förhållandet mellan gen och egenskap bli klart för studerande.

Tabell 1. Definitioner av de centrala begreppen inom genetik i de två finlandssvenska läroböckerna för gymnasiet.

\begin{tabular}{|c|c|c|}
\hline $\begin{array}{l}\text { Begrepp } \\
\text { eller } \\
\text { process }\end{array}$ & $\begin{array}{l}\text { Definitioner i Skolans biologi } \\
\text { (Leinonen m.fl., 2006) }\end{array}$ & $\begin{array}{l}\text { Definitioner i BIOS } 2 \\
\text { (Happonen m.fl., 2005) }\end{array}$ \\
\hline$D N A$ & $\begin{array}{l}\text { är en lång dubbelspiralformad molekyl } \\
\text { som består av nukleotider. DNA } \\
\text { innehåller den genetiska informationen } \\
\text { för alla organismer och flera virus. }\end{array}$ & $\begin{array}{l}\text { är en molekyl som innehåller cellernas } \\
\text { genetiska information. DNA är uppbyggt } \\
\text { av nukleotider med byggdelarna fosfat, } \\
\text { deoxiribossocker och en bas (A, T, G eller } \\
\text { C). DNA är en vriden dubbelspiral som } \\
\text { finns i kärnan, mitokondrierna och } \\
\text { kloroplasterna. }\end{array}$ \\
\hline Gen & $\begin{array}{l}\text { är en DNA-sekvens som finns i en } \\
\text { kromosom och som styr bildandet av ett } \\
\text { visst protein. Proteinet bidrar i sin tur } \\
\text { till utvecklingen av någon ärftlig } \\
\text { egenskap. }\end{array}$ & $\begin{array}{l}\text { är en sekvens av DNA-molekylen som styr } \\
\text { cellens och organismens livsfunktioner och } \\
\text { utveckling. }\end{array}$ \\
\hline Kromosom & $\begin{array}{l}\text { är en trådaktig del i cellkärnan som } \\
\text { består av proteiner och DNA och som } \\
\text { innehåller generna. }\end{array}$ & $\begin{array}{l}\text { är en kropp bestående av DNA och } \\
\text { proteiner, innehåller generna. } \\
\text { Kromosomerna finns i kärnan hos } \\
\text { eukaryota organismer, och deras antal är } \\
\text { artspecifikt. }\end{array}$ \\
\hline Genotyp & $\begin{array}{l}\text { är antingen en individs alla gener eller } \\
\text { t.ex. bara ett allelpar som påverkar en } \\
\text { egenskap och som undersöks i ett } \\
\text { aktuellt fall. }\end{array}$ & $\begin{array}{l}\text { är antingen summan av alla gener som } \\
\text { individen ärvt av sina föräldrar eller } \\
\text { allelkombinationen för varje genlocus. }\end{array}$ \\
\hline Fenotyp & $\begin{array}{l}\text { är egenskaper som uppkommer genom } \\
\text { samverkan mellan genotyp och } \\
\text { miljöfaktorer. Det kan vara frågan om } \\
\text { en enda egenskap eller summan av } \\
\text { organismens egenskaper. }\end{array}$ & $\begin{array}{l}\text { är antingen summan av alla synliga } \\
\text { egenskaper hos en organism, bestämd av } \\
\text { både genotypen och miljöfaktorerna eller } \\
\text { manifestationen av ett visst allelpar hos en } \\
\text { individ. }\end{array}$ \\
\hline Mitos & $\begin{array}{l}\text { är vanlig celldelning där cellernas } \\
\text { kromosomantal bibehålls. }\end{array}$ & $\begin{array}{l}\text { är kärndelning. Mitosen resulterar i två } \\
\text { kärnor som är lika till sin genotyp och } \\
\text { identiska med modercellen. }\end{array}$ \\
\hline Meios & $\begin{array}{l}\text { är celldelning, där de celler som bildas } \\
\text { har halva antalet kromosomer. Meiosen } \\
\text { förekommer främst då könsceller bildas. }\end{array}$ & $\begin{array}{l}\text { är celldelning som resulterar i att } \\
\text { könsceller bildas. Meiosen omfattar två } \\
\text { kärndelningar: reduktionsdelning och } \\
\text { mognadsdelning. Under meiosen halveras } \\
\text { det diploida kromosomantalet och en } \\
\text { omfördelning av det genetiska materialet } \\
\text { sker. }\end{array}$ \\
\hline
\end{tabular}




\section{GYMNASIETS GENETIK - SVÅRT ELLER BARA ETT DIDAKTISKT PROBLEM?}

\section{Kunskaper och missuppfattningar i genetik}

Det finns många studier från flera olika länder som visar att förståelsen av genetik och närliggande områden är svag hos elever i olika åldrar, såsom även hos befolkningen i allmänhet (Aldahmash \& Alshaya, 2012; Chattopadhyay, 2005; Chu \& Reid, 2012; Duncan, Freidenreich, Chinn \& Bausch, 2011; Lewis \& Kattman, 2004; Lewis, Leach \& WoodRobinson, 2000; Lewis \& Wood-Robinson 2000; Saka, Cerrah, Akdeniz \& Ayas, 2006). Svaga kunskaper i ämnet leder ofta till missuppfattningar eftersom eleverna lätt konstruerar en egen förståelse eller förklaring till fenomenet i fråga (Aldahmash \& Alshaya, 2012). Missuppfattningar är speciellt problematiska eftersom eleverna, istället för att inte veta, tror sig veta något, men som är felaktigt. Ofta är missuppfattningarna väl inbäddade i elevens kognitiva tankevärld och är svåra att få bort genom didaktiska metoder. Missuppfattningar anses därför vara den dominerande faktor som hindrar elevers inlärning i naturvetenskaper (Flodin, 2009; Kibuka-Sebitosi, 2007; Lewis \& Kattmann, 2004; Saka m.fl., 2006).

Missuppfattningar kan definieras som falska eller icke-vetenskapliga uppfattningar om begrepp, fenomen eller process. De grundar sig ofta på tidigare erfarenheter eller oförståelse av närliggande områden (Bahar, 2003; Lewis \& Kattmann, 2004). Speciellt vanliga verkar missuppfattningar vara inom ämnesområdena ärftlighet, sexuell och asexuell reproduktion samt celldelning (Aldahmash \& Alshaya, 2012; Burian, 2013; Chattopadhyay, 2005; Duncan m.fl., 2011; Kibuka-Sebitosi, 2007; Lewis m.fl., 2000; Lewis \& Kattmann, 2004; Shaw, Horne, Zhang \& Boughman, 2008; William, Debarger, Montgomery, Zhou \& Tate, 2012). Exempel på rapporterade missuppfattningar om begreppet gen är att gener är små partiklar som bär på egenskaper eller att genotyp och fenotyp inte kan särskiljas (Lewis \& Kattmann, 2004; Saka m.fl., 2006). Exempel på missuppfattningar om celldelning och genetisk informationsöverföring är att somatiska celler av olika typ (såsom hudceller och nervceller) innehåller olika information (Lewis \& Kattmann, 2004; Abdulwali \& Aldahmash, 2012), att flickor kommer att ärva moderns och pojkar faderns egenskaper samt att moderns medverkan är större än faderns (Banet \& Ayuso, 2000; Lewis \& Kattmann, 2004). Betydelsen av meios och meiosen som en process förklaras oftast bristfälligt och orsakerna anses ligga i mångfalden begrepp i läroböcker och undervisning (Quinn, Pegg \& Panizzon, 2009). Exempel på missuppfattningar och bristande kunskap om några grundläggande begrepp och processer är sammanställda i tabell 2. 
Tabell 2. Exempel på elevers missuppfattningar om genetiska begrepp och processer enligt tidigare forskning.

\begin{tabular}{|c|c|c|}
\hline Begrepp eller process & Missuppfattning & Källa \\
\hline DNA & $\begin{array}{ll}\checkmark & \text { har en enkel sträng } \\
\checkmark & \text { är gjord av kromosomer } \\
\checkmark & \text { är en bit av en gen } \\
\checkmark & \text { bildar blodgrupper } \\
\checkmark & \text { bestämmer identitet }\end{array}$ & $\begin{array}{l}\text { Duncan m.fl., 2011; Saka m.fl., } \\
\text { 2006; Shaw m.fl., } 2008\end{array}$ \\
\hline Gen & $\begin{array}{ll}\checkmark & \text { är en liten partikel som bär } \\
\checkmark & \text { på egenskaper } \\
\checkmark & \text { bildas av förenade } \\
\checkmark & \text { kromosomer } \\
\checkmark & \text { fer ut som en bakelse } \\
\checkmark & \text { bildas av DN fyra nukleotider } \\
\checkmark & \text { är ett DNA segment som } \\
& \text { innehåller receptet för en } \\
\checkmark & \text { polypeptid } \\
\checkmark & \text { är en enhet för länken } \\
\checkmark & \text { mellan förälder och barn } \\
& \text { finns alltid som två alleler: } \\
\text { dominerande och recessiva }\end{array}$ & $\begin{array}{l}\text { Aivelo \& Uitto, 2014; Duncan } \\
\text { m.fl., 2011; Flodin, 2009; } \\
\text { Lewis \& Kattmann, 2004; Saka } \\
\text { m.fl., } 2006\end{array}$ \\
\hline $\begin{array}{l}\text { Förhållandet mellan gener och } \\
\text { egenskaper }\end{array}$ & $\begin{array}{l}\checkmark \quad \text { Ifall en egenskap finns hos } \\
\text { en individ måste den även } \\
\text { ha funnits i någon av de } \\
\text { tidigare generationerna } \\
\checkmark \quad \text { Genen är en enhet för } \\
\text { ärftlighet som styr hurudan } \\
\text { en egenskap hos individen } \\
\text { är }\end{array}$ & $\begin{array}{l}\text { Flodin, 2009; Duncan m.fl. } \\
\text { 2011; Lewis \& Kattmann, } \\
\text { 2004; Lewis \& Wood- } \\
\text { Robinson, 2000; Lewis m.fl., } \\
2000\end{array}$ \\
\hline Kromosomer & $\begin{array}{ll}\checkmark & \text { är endera manliga eller } \\
& \text { kvinnliga } \\
\checkmark & \text { är speciella proteiner av } \\
& \text { DNA } \\
\checkmark & \text { består av dubbelspiral } \\
\checkmark & \text { bildas av förenade } \\
& \text { kromatider }\end{array}$ & $\begin{array}{l}\text { Lewis \& Kattmann, 2004; } \\
\text { Lewis m.fl., 2000; Saka, m.fl., } \\
2006\end{array}$ \\
\hline Genotyp och fenotyp & $\begin{array}{l}\checkmark \quad \text { Genotyp och fenotyp kan } \\
\text { inte särskiljas }\end{array}$ & $\begin{array}{l}\text { Lewis \& Kattmann , } 2004 \\
\text { Aivelo \& Uitto, } 2014\end{array}$ \\
\hline Mitos & $\begin{array}{ll}\checkmark & \text { Ursprungliga och nya } \\
& \text { hudceller innehåller olika } \\
& \text { genetisk information } \\
\checkmark & \text { Somatiska celler av olika } \\
& \text { typ innehåller olika } \\
\text { information } & \\
\checkmark & \text { Växtceller delar sig inte på } \\
& \text { samma sätt som djurceller }\end{array}$ & $\begin{array}{l}\text { Aldahmash \& Alshaya, 2012; } \\
\text { Lewis \& Kattmann, 2004; } \\
\text { Lewis \& Wood-Robinson, } \\
\text { 2000; Lewis m.fl., } 2000\end{array}$ \\
\hline Meios & $\begin{array}{ll}\checkmark & \text { Två spermier innehåller } \\
& \text { olika genetiska information } \\
\checkmark & \text { Antal kromosomer i en ny } \\
& \text { äggcell är två gånger } \\
& \text { orginalantalet eller samma } \\
& \text { som orginalantalet } \\
\checkmark & \text { Ingen skillnad mellan mitos } \\
\text { och meios }\end{array}$ & $\begin{array}{l}\text { Aldahmash \& Alshaya, 2012; } \\
\text { Duncan m.fl., } 2011 \\
\text { Quinn m.fl., } 2009\end{array}$ \\
\hline
\end{tabular}




\section{GYMNASIETS GENETIK - \\ SVÅRT ELLER BARA ETT DIDAKTISKT PROBLEM?}

\section{Genetikundervisning i skolan}

En annan orsak till varför genetik upplevs som ett svårt ämnesområde kan bero på hur ämnet undervisas i skolan. Enligt Elmesky (2013) och Flodin (2009) beskrivs det inte tydligt i läroplanerna eller andra styrdokument, vad exakt, vilka helheter och i vilken ordning genetikstoffet borde undervisas. Vikten av att strukturera och bygga upp begreppen från daghem till gymnasium, och därmed kunna följa upp progressionen i elevers tänkande och lärande, betonas inte tillräckligt (Elmesky, 2013). Likaså saknas rekommendationer och motiveringar till optimala undervisningsmetoder och arbetssätt som gynnar elevers inlärning i genetik. Det minsta som borde göras i början av varje genetikkurs är att med hjälp av diagnostiska prov ta reda på elevers förkunskaper och missuppfattningar (Eloranta, Jeronen \& Palmberg, 2005; Krüger, Fleige \& Riemeier, 2006).

Åsikterna och slutsatserna om hur genetikundervisningen borde organiseras är dock motstridiga. Enligt t.ex. Burian (2013) ska undervisningen vara processfokuserad istället för modellbaserad där man lägger för mycket vikt vid små detaljer. Rotbain m.fl. (2005) däremot har konstaterat att elever som fătt arbeta med och använda sig av olika inlärningsmodeller lärt sig genetiska helheter och detaljer bäst. De har använt olika illustrationsmodeller och ritat upp t.ex. en DNA-sträng. Ännu bättre inlärningsresultat nåddes då eleverna fick bygga och pyssla med 3D-modeller av DNA (Rotbain m.fl., 2006). Resultat även från andra undersökningar (t.ex. Rothhaar, Pittendrigh \& Orvis, 2006; Saka m.fl. 2006) stöder principen om att visuell framställning med hjälp av pappmodeller, bilder och analogier förstärker elevers inlärning i genetik. Dessutom visar undersökningen (Rotbain, m.fl., 2006) att användningen av flera olika hjälpmedel i visualiseringen, t.ex. datorer eller pekplattor, ytterligare förbättrar inlärningsresultaten. Kombinationen av analogier och hands-on aktiviteter hjälper ytterligare elever att förstå abstrakta genetiska helheter.

Lärande av nytt stoff tenderar att vara lättare om man är intresserad av det man lär sig. För att väcka elevers intresse för genetik kunde aktiva studiebesök till olika vetenskapscenter inkorporeras i undervisningen. Forskningsresultat (Dairianathan \& Subramaniam, 2011) visar nämligen att ett välorganiserat besök till ett vetenskapscenter ökade elevers förståelse om nedärvning, DNA och gener. Om eleverna dessutom deltog i olika program där de själva fick jobba med olika uppgifter (t.ex. hands-on aktiviteter, aktiviteter med alla sinnen, DNA-detektiver, mysterier och social växelverkan) visade det sig att utöver ett ökat intresse för ämnet var den erhållna kunskapen stabil och bibehölls en längre tid. Ett annat sätt att väcka intresse för genetik hos elever är att i undervisningen använda problembaserade övningsuppgifter och simuleringar som har direkt med elevernas vardag att göra (Gelbart \& Yarden, 2006). Inom genetiken kan det t.ex. vara frågan om att använda uppgifter där eleverna ska reda ut bakgrunden till en genmutation som ger upphov till en för eleverna känd sjukdom, t.ex. Downs syndrom eller skärcellsanemi. För att kunna 
väcka intresse och handleda eleverna i forskningsprocessen är det viktigt att läraren håller sig väl uppdaterad i ämnet.

En annan aspekt som påpekas av Chu \& Reid (2012) är elevers kapacitet i form av arbetsminne. Arbetsminnet är begränsat och inverkar på hur mycket eleverna kan ta till sig av undervisningen på en och samma gång. Genom att utveckla undervisningsmetoderna så att arbetsminnet inte belastas till sin maximala kapacitet kan man uppnå signifikant bättre inlärningsresultat. Dessa förbättringar kan göras genom att a) sekvensera upp det nya lärostoffet i mindre delar, b) dela upp större komplexa helheter i mindre segment så att mängden information som belastar arbetsminnet på en gång blir mindre, c) tydligt informera eleverna om vad det är de ska lära sig, varför och hur, d) reservera tillräckligt med tid för frågor och diskussion i undervisningen, e) koppla ihop det inlärda stoffet med elevernas verklighet och vardag.

\section{Testresultat och diskussion}

Med hjälp av sex flervalsfrågor (tabell 4) undersöktes gymnasiestuderandes förståelse av några grundläggande begrepp och processer i genetik. Resultaten visar att endast ett fåtal studerande hade förstått vad de undersökta begreppen och processerna betyder. De ansåg sig också vara säkra på sina svar. En stor majoritet var dock osäker på sina svar, trots att de flesta redan hade avlagt den huvudsakliga gymnasiekursen i genetik. Dessutom ansåg en del av de som svarat fel att de var säkra på sitt svar. Genetik upplevdes som svårt eller lätt oberoende av hur många poäng som erhållits i testet. Resultaten redovisas nedan i detalj och diskuteras vartefter i ljuset av de tidigare forskningsresultaten.

\subsection{Gymnasiestuderandes kunskaper och missuppfattningar i genetik}

Trots att flervalstestet tog upp endast mycket centrala begrepp och processer i genetik (enligt läroplanen och läroböckerna) kunde endast fyra av de 46 gymnasiestuderandena svara rätt på alla sex frågor och 44 \% på över hälften av frågorna. Av de övriga svarade 28 \% rätt endast på en eller två frågor, medan en studerande inte hade ett enda rätt svar (tabell 3). De åtta personer som inte ännu avlagt kurs 2, som är en huvudsaklig källa för genetikkunskapen i gymnasiet, avklarade två till fyra frågor. Männens medeltal $(3,7)$ var något högre än kvinnornas $(3,1)$. Huruvida detta resultat är statistiskt signifikant testades inte på grund av den ringa sampelstorleken.

Tabell 3. Översikt av gymnasiestuderandes antal poäng i testet i förhållande till avlagd kurs 2.

\begin{tabular}{ccccc}
\hline Poäng & $\begin{array}{c}\text { Män } \\
(\mathrm{n}=15)\end{array}$ & Kvinnor $(\mathrm{n}=31)$ & $\begin{array}{c}\text { Totalt } \\
(\mathrm{N}=46)\end{array}$ & $\begin{array}{c}\text { Avlagt kurs 2: } \\
\text { Ja/Nej }\end{array}$ \\
\hline 6 & $2(13 \%)$ & $2(6 \%)$ & $4(9 \%)$ & $4 /-$ \\
5 & $3(20 \%)$ & $3(10 \%)$ & $6(13 \%)$ & $6 /-$ \\
4 & $4(27 \%)$ & $6(19 \%)$ & $10(22 \%)$ & $8 / 2$ \\
3 & $3(20 \%)$ & $9(29 \%)$ & $12(26 \%)$ & $8 / 4$ \\
2 & - & $8(26 \%)$ & $8(17 \%)$ & $6 / 2$ \\
1 & $3(20 \%)$ & $2(6 \%)$ & $5(11 \%)$ & $5 /-$ \\
0 & - & $1(3 \%)$ & $1(2 \%)$ & $1 /-$ \\
Medeltal & 3,7 & 3,1 & 3,3 & \\
\hline
\end{tabular}




\section{GYMNASIETS GENETIK - SVÅRT ELLER BARA ETT DIDAKTISKT PROBLEM?}

Av alla frågor (tabell 4) besvarades frågan om förhållandet mellan en gen och en egenskap bäst (65 \% hade rätt), följt av påståenden om kromosomen (57 \%) och genen (57 \%). Över hälften av de studerande (53 \%) kunde svara rätt på frågan om meiosen. Likaså kunde $50 \%$ svara rätt på tillämpningsfrågan om mitosen och DNA, medan 48 \% kunde tillämpa sin kunskap om DNA angående olika färger på blommorna. Då de som svarat rätt tillfrågades om hur säkra de var på sina svar ansåg 73 \% sig vara säkra på svaret om genen, 67 \% om förhållandet mellan gen och egenskap och $65 \%$ om kromosomen, medan 48 \% var säkra på svaret om hudcellen, $42 \%$ om meiosen och endast $36 \%$ om orsaken till olika färger hos blommor.

Betydligt sämre var situationen bland dem som svarat fel, eftersom t.ex. upp till $65 \%$ av dem var säkra på sitt svar om kromosomen. Procenten studerande, som trots sina felaktiga svar var säkra på sina svar, varierade mellan 8 och 65 (se tabell 4). De var med andra ord inte medvetna om sina missuppfattningar. Missuppfattningar är en viktig faktor som anses hindra elevers fortsatta inlärning i temat (t.ex. Flodin, 2009; Kibuka-Sebitosi, 2007; Saka m.fl., 2006; dos Santos m.fl., 2012). De studerande (41 \%) som valt t.ex. svarsalternativet "alla celler i en frisk människokropp har 46 kromosomer" har inte förstått könscellernas roll i kroppen, vilket också framkommer i det felaktiga svarsalternativet "varje dottercell får hälften av kromosomantalet då en hudcell delar sig" (valts av 24 \%). Det felaktiga svarsalternativet "fröna innehåller olika typer av pigment" som orsak till olika blomfärger (valts av $35 \%$ ) eller "egenskapen finns inne i genen" som förklaring till förhållandet mellan gen och egenskap (valts av 30 \%) bevittnar om okunskap om DNA. Oförståelse om skillnader mellan mitos och meios kommer fram även i svaren "DNA i modercellen delar sig i två strängar och var och en av dottercellerna får en av dessa två strängar" då en hudcell delar sig (valts som svar av 22 \%) eller "meiosen resulterar i fyra nya celler med samma genetiska material" (valts av $31 \%$ ). Motsvarande missuppfattningar har förekommit rikligt även i tidigare forskning (jämför tabell 2). 
Tabell 4. Testfrågorna och svarsalternativen samt hur gymnasiestuderande svarat procentuellt på de fyra svarsalternativen per fråga och hur säkra de varit på sina svar. Det rätta alternativet anges med kursiv stil.

\begin{tabular}{|c|c|c|c|}
\hline \multicolumn{2}{|r|}{ Fråga } & Svarsalternativ & \multirow{2}{*}{$\begin{array}{c}\text { Svar } \\
(\%)\end{array}$} \\
\hline 1. & En gen är & a) en egenskap hos organismen & \\
\hline & & b) en egenskap som ärvs från en generation till nästan & 13 \\
\hline & & $\begin{array}{l}\text { c) en aminosyrasekvens som är ansvarig för överföringen av en } \\
\text { egenskap från en generation till nästa }\end{array}$ & 28 \\
\hline & & d) ett avsnitt av DNA som kodar för protein & 57 \\
\hline & Är du säker på ditt & $\mathrm{Ja}$, av respondenter som svarat rätt & 73 \\
\hline & svar? & $\mathrm{Ja}$ av respondenter som svarat fel & 45 \\
\hline \multirow[t]{6}{*}{2.} & Vilket är förhållandet & a) Genen är en egenskap & 2 \\
\hline & mellan en gen och en & b) Egenskapen finns inne i genen & 30 \\
\hline & egenskap? & c) Genen är ett resultat av egenskapen & 2 \\
\hline & & d) Egenskapen är ett resultat av genens produkt & 65 \\
\hline & Är du säker på ditt & Ja, av respondenter som svarat rätt & 67 \\
\hline & svar? & Ja, av respondenter som svarat fel & 25 \\
\hline \multirow[t]{6}{*}{3.} & Vilket av följande & a) Kromosomerna är uppbyggda av DNA och proteiner (histoner) & 57 \\
\hline & påståenden om & b) Kromosomerna är manliga eller kvinnliga & 2 \\
\hline & kromosomen är rätt? & c) Alla celler i en frisk människokropp har 46 kromosomer & 41 \\
\hline & & $\begin{array}{l}\text { d) Ju fler kromosomer en organism har, desto mer utvecklad är } \\
\text { den }\end{array}$ & 0 \\
\hline & Är du säker på ditt & Ja, av respondenter som svarat rätt & 65 \\
\hline & svar? & Ja, av respondenter som svarat fel & 65 \\
\hline \multirow[t]{6}{*}{4.} & När en hudcell delar & a) Varje dottercell får hälften av kromosomantalet & 24 \\
\hline & $\begin{array}{l}\text { sig, vad händer med } \\
\text { dess DNA? }\end{array}$ & $\begin{array}{l}\text { b) DNA i modercellen delar sig i två strängar och var och en av } \\
\text { dottercellerna făr en av dessa två strängar }\end{array}$ & 22 \\
\hline & & $\begin{array}{l}\text { c) Den ena dottercellen får den ursprungliga DNA-molekylen och } \\
\text { den andra dottercellen får den nya DNA-molekylen }\end{array}$ & 4 \\
\hline & & $\begin{array}{l}\text { d) En komplementär ny DNA-sträng byggs upp enligt sekvensen i } \\
\text { den ursprungliga strängen och varje dottercell får en molekyl } \\
\text { som består av en ny sträng och en ursprunglig sträng }\end{array}$ & 50 \\
\hline & Är du säker på ditt & Ja, av respondenter som svarat rätt & 48 \\
\hline & svar? & Ja, av respondenter som svarat fel & 30 \\
\hline \multirow[t]{6}{*}{5.} & Vilket av följande & a) Varannan gång en cell delar sig så sker det genom meios & 7 \\
\hline & $\begin{array}{l}\text { påståenden om } \\
\text { meiosen är rätt? }\end{array}$ & $\begin{array}{l}\text { b) Meiosen resulterar i fyra nya celler med samma genetiska } \\
\text { material }\end{array}$ & 31 \\
\hline & & c) Meiosen omfattar två kärndelningar & 53 \\
\hline & & $\begin{array}{l}\text { d) Meiosen resulterar I två nya celler med olika genetiska } \\
\text { material }\end{array}$ & 9 \\
\hline & Är du säker på ditt & $\mathrm{Ja}$, av respondenter som svarat rätt & 42 \\
\hline & svar? & Ja, av respondenter som svarat fel & 48 \\
\hline \multirow[t]{6}{*}{6.} & Ärtfrön planteras i & a) Fröna innehåller olika typer av pigment & 35 \\
\hline & $\begin{array}{l}\text { trädgărden. Plantorna } \\
\text { som gror från dessa }\end{array}$ & b) Fröna innehåller DNA som består av olika typer av nukleotider & 13 \\
\hline & $\begin{array}{l}\text { frön har olika färgers } \\
\text { blommor. Vilken är }\end{array}$ & c) Fröna innehåller DNA som består av olika nukleotidskevenser & 48 \\
\hline & $\begin{array}{l}\text { skillnaden mellan de } \\
\text { frön som ger upphov } \\
\text { till de olika } \\
\text { blomfärgerna? }\end{array}$ & d) Fröna innehåller olika typer av ribosomer & 4 \\
\hline & Är du säker på ditt & Ja, av respondenter som svarat rätt & 36 \\
\hline & svar? & Ja, av respondenter som svarat fel & 8 \\
\hline
\end{tabular}

Den höga procenten felaktiga svar är förvånansvärd, eftersom de flesta av studerandena redan hade avlagt den obligatoriska gymnasiekursen om genetik (utöver att genetikens 


\section{GYMNASIETS GENETIK - SVÅRT ELLER BARA ETT DIDAKTISKT PROBLEM?}

grunder redan behandlats på högstadiet). Dessutom hade en del avklarat även fördjupningskursen i genetik (kurs 5) samt ett flertal andra biologikurser. Eftersom samplet var litet kan inte resultaten generaliseras. Dock kan effekten av t.ex. antalet avlagda kurser i genetik förväntas vara en variabel som ökar kunnandet. I vårt test hade tre av de fyra som fick fulla sex poäng i testet avklarat både grund- och fördjupningskursen i genetik, medan den fjärde endast hade grundkursen. Endast en av de sex studerande som fått fem rätt hade både grund- och fördjupningskursen avklarade, medan det bland de 14 som fått endast två eller färre rätt även fanns sådana som utöver grundkursen hade avklarat fördjupningskursen eller höll på med den. En avlagd fördjupningskurs kunde med andra ord inte förklara skillnaderna i vårt test.

\subsection{Svårighetsgraden i genetik enligt gymnasiestuderande}

Vi frågade även om gymnasiestuderande upplever genetik som ett svårt eller lätt skolämne. Över hälften av dem (57 \%) tyckte att genetik är medelsvårt, medan endast $15 \%$ upplevde ämnet som svårt, bland dem den studerande som fått fulla poäng i testet (se tabell 5). I motsats till den tidigare forskningen (t.ex. Chu \& Reid, 2012; Kibuka-Sebitosi, 2007; Lewis \& Kattmann, 2004; Tsui \& Treagust, 2010) ansåg ingen av de undersökta att genetik är mycket svårt, inte ens de 14 som fått två eller färre poäng i testet. Däremot tyckte $28 \%$ att genetik är mycket lätt eller lätt, bland dem även de två studerande som endast fått en poäng i testet.

Tabell 5. Gymnasiestuderandes poäng i testet och deras uppfattning om genetik (bokstaven efter antalet studerande anger könet: K, kvinna; M, man)

\begin{tabular}{cccccc}
\hline Poäng & Mycket lätt & Lätt & Medelsvårt & Svårt & Mycket svårt \\
\hline 6 & $1 \mathrm{M}$ & $1 \mathrm{M}$ & $1 \mathrm{~K}$ & $1 \mathrm{~K}$ & - \\
5 & $1 \mathrm{M}$ & $1 \mathrm{M}$ & $3 \mathrm{~K}+1 \mathrm{M}$ & - & - \\
4 & - & $2 \mathrm{M}$ & $5 \mathrm{~K}+2 \mathrm{M}$ & $1 \mathrm{~K}$ & - \\
3 & $1 \mathrm{~K}$ & $2 \mathrm{~K}+2 \mathrm{M}$ & $6 \mathrm{~K}+1 \mathrm{M}$ & - & - \\
2 & - & $1 \mathrm{~K}$ & $4 \mathrm{~K}$ & $3 \mathrm{~K}$ & - \\
1 & - & $1 \mathrm{M}$ & $1 \mathrm{~K}+2 \mathrm{M}$ & $1 \mathrm{~K}$ & - \\
0 & - & - & - & $1 \mathrm{~K}$ & - \\
Totalt & $3(6 \%)$ & $10(22 \%)$ & $26(57 \%)$ & $7(15 \%)$ & 0 \\
\hline
\end{tabular}

Inget samband kunde ses mellan testresultat och studerandes uppfattning om huruvida ämnet är svårt eller lätt. Det fanns dock skillnader mellan männens och kvinnornas åsikter. Männen var mer benägna att tycka att genetik inte är svårt (och hade också bättre medeltal i testet) än kvinnorna. För $64 \%$ av männen är genetik lätt eller mycket lätt, medan motsvarande procent för kvinnorna är 13. Ingen av männen tyckte att genetik är svårt eller mycket svårt, vilket $22 \%$ av kvinnorna gjorde. 


\subsection{Svårighetsgraden i skolböcker inom genetik enligt gymnasiestuderande}

Eftersom läroböcker kan vara en av orsakerna till varför genetik ofta uppfattas som svårt att förstå (Gericke m.fl., 2012; dos Santos m.fl., 2012), analyserade vi först de aktuella skolböckerna angående de centrala begreppen (se tabell 1). Därefter frågade vi gymnasiestuderandenas uppfattning om skolböckerna i genetik för grundkursen och analyserade denna i förhållande till testresultaten (tabell 6). Trots att resultat från olika läroboksanalyser lyfter fram brister och inkonsekvenser i böckerna (t.ex. Aivelo \& Uitto, 2014b; Flodin, 2009; Gericke, 2009; dos Santos m.fl., 2012), tyckte över hälften av de undersökta gymnasiestuderandena (63\%) att deras genetikbok - Bios 2 - var lätt eller mycket lätt att förstå, medan resten (37 \%) ansåg den vara bara medelsvår. Inget samband fanns mellan testresultat och hur lätt eller svår studerande upplevde att läroboken är. Många av de som hade lägre poäng i testet ansåg att boken var lättförståelig. Av männen tyckte $79 \%$ att boken var lätt eller mycket lätt, medan motsvarande procent för kvinnorna $\operatorname{var} 56$.

Tabell 6. Gymnasiestuderandes uppfattning om läroböcker i genetik och deras poäng i testet. (bokstaven efter antalet studerande anger könet: K, kvinna; M, man)

\begin{tabular}{ccccccc}
\hline Poäng & $\begin{array}{c}\text { Mycket lätt } \\
\text { att förstå }\end{array}$ & $\begin{array}{c}\text { Lätt att } \\
\text { förstå }\end{array}$ & $\begin{array}{c}\text { Medelsvårt } \\
\text { att förstå }\end{array}$ & $\begin{array}{c}\text { Svårt } \\
\text { att } \\
\text { förstå }\end{array}$ & $\begin{array}{c}\text { Mycket svårt } \\
\text { att förstå }\end{array}$ & $\begin{array}{c}\text { Inget } \\
\text { svar }\end{array}$ \\
\hline 6 & $1 \mathrm{M}$ & $1 \mathrm{M}$ & $2 \mathrm{~K}$ & - & - & \\
5 & - & $3 \mathrm{~K}$ & $3 \mathrm{~K}$ & - & - & \\
4 & - & $3 \mathrm{~K}+1 \mathrm{M}$ & $2 \mathrm{~K}+3 \mathrm{M}$ & - & - & 1 \\
3 & $1 \mathrm{~K}$ & $4 \mathrm{~K}+2 \mathrm{M}$ & $2 \mathrm{~K}$ & - & - & 3 \\
2 & - & $5 \mathrm{~K}$ & $2 \mathrm{~K}$ & - & - & 1 \\
1 & - & $2 \mathrm{~K}+3 \mathrm{M}$ & - & - & - & \\
0 & - & - & $1 \mathrm{~K}$ & - & - & \\
Totalt & $2(4 \%)$ & $24(59 \%)$ & $15(37 \%)$ & 0 & 0 & 5 \\
\hline
\end{tabular}

\subsection{Gymnasiestuderandes uppfattningar om sitt eget sätt att lära sig genetik bäst}

Enligt forskningen är undervisningsmetoderna ofta en orsak till inlärningsproblem i genetik (Baker \& Lawson, 2001; Johnson \& Stewart, 2002; Rotbain m.fl., 2006; Templin \& Fetters, 2002a, b). Lärare har ett stort urval av olika undervisningsmetoder och arbetssätt att tillgå (se Palmberg, 2005), men forskningen är oense om hur genetikundervisningen egentligen borde organiseras (se avsnittet om genetikundervisning i skolan). Eftersom lärandet är olika för olika personer frågade vi gymnasiestuderande i en öppen fråga hur de anser att de lär sig genetik bäst. Innehållet i deras svar grupperades i sex kategorier: framställande undervisning, självständig läsning, övningar, visualisering, informationssökning på Internet och "vet inte".

Över hälften av de studerande (61 \%) nämnde framställande undervisning som en viktig del i sitt lärande och betonade därmed lärarens roll som föreläsare. De poängterade vikten av 


\section{GYMNASIETS GENETIK - SVÅRT ELLER BARA ETT DIDAKTISKT PROBLEM?}

att "följa med på lektionerna”, att läraren berättar, men också att de gör anteckningar under dessa lärarledda lektioner. En studerande uttryckte det så här: När någon förklarar åt mig genom att visa på PowerPoint och jag skriver ner det, en annan: Att vara på lektionen och lyssna + anteckna, medan en tredje kombinerade flera sätt: Lyssna på läraren, läsa kursboken och forska på nätet. Andra studerande satte dessutom ansvaret helt på läraren: Det beror en hel del på läraren, det måste göras intressant eller Lyssna på timmarna, bara att läraren kan förklara bra. I denna kategori fanns studerande som fătt fem poäng av sex, men även sådana som endast fått en poäng.

Självständig läsning ingick i lärandet hos $37 \%$ av de studerande. En del av dem svarade kort och utan att precisera att de lär sig bäst: genom att läsa, medan andra inkluderade läsningen bland de övriga sätten: genom att lyssna på läraren, skriva ner i häftet, kolla upp saker på internet, och läsa förståss. Bl.a. en studerande som fått fulla poäng hör till denna kategori och förklarar sitt lärande enkelt med: Läser boken.

Vikten av övningsuppgifter (t.ex. olika korsningar och problemlösning) betonades av $17 \%$ av de studerande. En del av dem lyfte fram endast övningsuppgifter, medan andra inkluderade dem i ett flertal andra sätt att lära sig: Först läser jag igenom det material vi fått (bok, papper) sedan frågar jag sånt som är oklart, kollar ibland upp på nätet. J ag lär mig också genom övningar, t.ex. korsningsscheman.

Visualiseringen ingick i lärande hos $24 \%$ av de studerande. De betonade vikten av filmer, bilder, animationer och överlag konkretisering steg för steg. En studerande med tre poäng i testet förklarade sitt lärande genom att studera bilder och titta på videoklipp om hur det går till, medan en annan med fem poäng förklarade: Genom att någon visar vad som händer (genom film eller med modeller) istället för att bara lära sig genom att läsa.

Ca 7 \% nämnde också informationssökningen på Internet (som i de tidigare exemplen om läsning och övningar), men ingen nämnde enbart detta som sitt bästa sätt att lära sig genetik.

Till den sista kategorin placerades de $15 \%$ av studerandena som svarat antingen vet inte eller har inte ännu lärt mig. De senare hörde till gruppen som inte ännu avlagt genetikkursen i gymnasiet, men kunde på basis av högstadiegenetik svara rätt på 2-4 frågor.

De fyra studerande, två kvinnor och två män, som hade allt rätt i testet, lärde sig på olika sätt. Den ena kvinnan beskrev utförligt ett exempel: Läraren hade ett "skådespel" på tavlan med utklippta förstorade nukleotider, ribosomer, RNA, osv. Vi gjorde uppgifter i klassen, medan den andra lärde sig genom övningsuppgifter. Den ena mannen lärde sig genom bilder och den andra genom att läsa boken. Den studerande, en kvinna, som fick noll poäng i testet förklarade sitt lärande på följande sätt: någon som på riktigt vet och kan ämnet lär ut det samt att göra uppgifter (bra uppgifter), medan de tre män och två kvinnor som fick en poäng i testet huvudsakligen betonade höra på, följa med lektioner, 
anteckna och läsa boken. Två av dem nämnde dessutom läxläsning och förhör så man måsteläsa.

Som det framkommer i exemplen ovan varierade studerandes åsikter om hur de lär sig bäst och vi kunde inte hitta något samband mellan testresultaten och inlärningssätten. Intressant är dock att denna grupp av gymnasiestuderande starkt betonar lärarens aktiva roll. Lärare ska med andra ord både kunna själva ämnet och kunna förklara det, i stället för att de studerande själva tar ansvar för sitt lärande.

\section{Slutdiskussion}

I motsats till tidigare forskningsresultat (t.ex. Chattopadhyay, 2005; Chu \& Reid, 2012; Gericke \& Hagberg, 2007; Kibuka-Sebitosi, 2007; Lewis \& Kattmann, 2004; Rotbain, Marbach-Ad \& Stavy, 2006; Tsui \& Treagust, 2010) ansåg de 46 gymnasiestuderandena att genetik inte är svårt, trots att endast fyra av dem kunde svara rätt på samtliga frågor. Ingen av dem tyckte heller att läroboken var svår att förstå. Resultatet var i själva verket betydligt sämre, eftersom många av de studerande som svarat rätt, var osäkra på sina svar, medan en stor del av de som svarat fel, i sin tur, var säkra på sina svar. De felaktiga alternativ som lockat studerande i denna undersökning har varit populära även i tidigare forskning (se t.ex. Abdulwali \& Aldahmash, 2012; Lewis \& Kattmann, 2004; Quinn m.fl., 2009; Rotbain m.fl., 2005, 2006; Saka m.fl., 2006). Missuppfattningar och bristande kunskap är enligt tidigare forskning ett hinder för fortsatt inlärning (Flodin, 2009; KibukaSebitosi, 2007; Saka m.fl., 2006; dos Santos m.fl., 2012) och borde därför noggrant kartläggas före varje kurs och därefter beaktas vid planeringen av undervisningen.

Vid analysen av gymnasiets läroplan, GGL 2003, kan man konstatera att ramarna för gymnasieundervisningen i Finland är överlag väldigt teoretiska och faktabetonade. Så är det även med kursmålen i genetik, med undantag av det enda metodiska målet att de studerande ska behärska experimentella arbetssätt. Läroplanen ställer inga krav på undervisningsmetoder, inte heller ger den förslag på olika sätt att nå de teoretiska målen. Lärarens roll som "berättare" och föreläsare med färdiga svar på allt ansågs vara avgörande för lärande i genetik bland majoriteten av de studerande i denna undersökning, oberoende av hur de lyckades i testet. Visserligen ingick behovet av visualisering i olika former i en del av de studerandes bästa sätt att lära sig genetik, medan andra lyfte fram betydelsen av övningsuppgifter. De nämnda övningsuppgifterna, t.ex. korsningsscheman, var alla teoretiska, och ingen av de studerande nämnde övningsuppgifter av praktisk natur (t.ex. problembaserade laborationer eller korsningsförsök). Det faktum att de studerande inte upplevde genetiken eller genetikboken som svår, men ändå i testresultaten visade att de inte lärt sig genom de sätt de ansåg vara de bästa, väcker många frågor. Visserligen är samplet för litet för att man ska kunna dra några långtgående slutsatser, men tillsammans med motsvarande resultat från tidigare forskning kunde några synpunkter beaktas vid bearbetningen av en ny läroplan för gymnasiet. Läroplanen borde på basis av 


\section{GYMNASIETS GENETIK - SVÅRT ELLER BARA ETT DIDAKTISKT PROBLEM?}

forskningsresultat (t.ex. Dairianathan \& Subramaniam, 2011; Gelbart \& Yarden, 2006; Rotbain m.fl., 2006; Rothhaar m.fl., 2006; Saka m.fl., 2006) tydligare lyfta fram de undervisningsformer och arbetssätt som stöder inlärningen av abstrakta begrepp och processer samt ger färdigheter till tillämpningar. Läroplanen styr nämligen i hög grad även innehållet i läroboken, vilket framkommer bland annat om man jämför den aktuella läroplanen med de två läroböckerna för kurs 2 i genetik (se tidigare).

Enligt de studerande är läroboken inte svår att förstå, men det säger ingenting om hur vetenskapligt rätt och välstrukturerad boken är. Dessutom framhäver tidigare forskningsresultat många brister och inkonsekvenser i läroböcker (Aivelo \& Uitto, 2014a, b; Gericke, 2009; Gericke m.fl., 2012; dos Santos m.fl., 2012). Uppdateringarna av läroböcker borde hålla samma takt som den snabba utvecklingen inom genetik och närliggande vetenskapsområden, likaså anordnandet av fortbildning för lärare. 


\section{Referenser}

Aivelo, T. \& Uitto, A. (2014a). Geenimallit lukion oppikirjoissa ja lukiolaisten käsityksiä geenien toiminnasta. Natura 2, 31-35.

Aivelo, T. \& Uitto, A. (2014b). Finnish upper secondary school biology textbooks have outdated gene models. Proposal and paper presentation at NFSUN-2014, 4-6.6.2014.

Aldahmash, A.H. \& Alshaya, F.S. (2012). Secondary school students' alternative conceptions about genetics. Electronic J ournal of Science Education 16(1), 1-21.

Bahar, M. (2003). Misconceptions in biology education and conceptual change strategies. Educational Sciences: Theory \& Practice 3(1), 55-64.

Baker, W.P. \& Lawson, A.E. (2001). Complex instructional analogies and theoretical concept acquisition in college genetics. Science Education 85(6), 665-683.

Banet, E. \& Ayuso, G. E. (2003). Teaching of biological inheritance and evolution of living beings in secondary schools. International J ournal for Science Education 25, 373-407.

Burian, R.M. (2013). On gene concepts and teaching genetics: episodes from classical genetics. Science \& Education 22, 325-344.

Chattopadhyay, A. (2005). Understanding of genetic information in higher secondary students in Northeast India and the implications for genetics education. Cell Biology Education 4(1), 97-104.

Chu, Y-C. \& Reid, N. (2012). Genetics at school level: addressing the difficulties. Research in Science \&Technological Education 30(3), 285-309.

Dairianathan, A. \& Subramaniam, R. (2011). Learning about inheritance in an out-of-school setting. International J ournal of Science Education 33(8), 1079-1108.

Dikmenli, M. (2010). Misconception of cell division held by student teachers in biology: A drawing analysis. Scientific Research and Essay 5(2), 235-247.

Duncan, R.G., Freidenreich, H.G., Chinn, C.A. \& Bausch, A. (2011). Promoting middle school students' understandings of molecular genetics. Research in Science Education 41, 147-167.

Elmesky, R. (2013). Building capacity in understanding foundational biology concepts: A K-12 learning progression in Genetics informed by research on children's thinking and learning. Research in Science Education 43, 1155-1175.

Flodin, V. S. (2009). The necessity of making visible concepts with multiple meanings in science education: the use of the gene concept in biology textbook. Science \& Education 18, 73-94.

Gelbart, H. \& Yarden, A. (2006). Learning genetics through an authentic research simulation in bioinformatics. J ournal of Biological Education 40(3), 107-112.

Gericke, N. (2009). Science versus School-science. Multiple models in genetics - The depiction of gene function in upper secondary textbooks and its influence on students' understanding. Studies in Science and Technology Education No 27, Linköping University, Norrköping, Department of Social and Welfare Studies. (Dr.avhandling)

Gericke, N \& Hagberg, M. (2007). Definition of historical models of gene function and their relation to students' understanding of genetics. Science \& Education 16, 849-881.

Gericke, N.M. \& Hagberg, M. (2010a). Conceptual variation in the depiction of gene function in upper secondary school textbooks. Science \& Education 19, 963-994.

Gericke, N. M. \& Hagberg, M. (2010b). Conceptual incoherence as a result of the use of multiple historical models in school textbooks. Research in Science Education, 40(4), 605-623.

Gericke, N.M., Hagberg, M. \& Jorde, D. (2012). Upper secondary students' understanding of the use of multiple models in biology textbooks - The importance of conceptual variation and incommensurability. Research in Science Education, doi: 10.1007/s11165-012-9288-z.

Gericke, N.M., Hagberg, M., dos Santos, V.C., Joaquim, L.M. \& El-Hani, C.N. (2012). Conceptual variation or incoherence? Textbook discourse on genes in six countries. Science \&Education. doi: 10.1007/s11191-012-9499-8

Grunderna för gymnasiets läroplan, GGL (1985). Helsingfors: Skolstyrelsen. 


\section{GYMNASIETS GENETIK -
SVÅRT ELLER BARA ETT DIDAKTISKT PROBLEM?}

Grunderna för gymnasiets läroplan, GGL (1994). Helsingfors: utbildningsstyrelsen.

Grunderna för gymnasiets läroplan, GGL (2003). Helsingfors: Utbildningsstyrelsen. http://www02.oph.fi/svenska/ops/gymnasiet/gymnlpg.pdf

Grunderna för läroplanen för den grundläggande utbildningen, GLGU (2004). Helsingfors: Utbildningsstyrelsen. http://www02.oph.fi/svenska/ops/grundskola/LPgrundl.pdf

Happonen, P., Holopainen, M., Sotkas, P., Tenhunen, A., Tihtarinen-Ulmanen, M. \& Venäläinen, J. (2005). Bios 2, Cellen och ärftligheten. Helsingfors: Söderströms.

Johnson, S. \& Stewart, J. (2002). Revising and assessing explanatory models in a high school genetics class: a comparison of unsuccessful and successful performance. Science Education 86, $463-480$.

Jortikka, S., Leinonen, M., Nyberg, T., Veistola, S. \& Flemmig, L-L. (2013). Skolans biologi, Människan. Helsingfors: Schildts \& Söderströms.

Kibuka-Sebitosi, E. (2007). Understanding genetics and inheritance in rural schools. J ournal of Biological Education 41(2), 56-61.

Krüger, D., Fleige, J. \& Riemeier, T. (2006). How to foster an understanding of growth and cell division. J ournal of Biological Education 40(3), 135-140.

Leinonen, M., Nyberg, T., Tast, J., Tyrväinen, H., Veistola, S. \& Sandvik, A. (2006). Skolans biologi, Cellen och ärftligheten. Helsingfors: Schildts.

Lewis, J. \& Kattmann, U. (2004). Traits, genes, particles and information: re-visiting students' understanding of genetics. International J ournal of Science Education 26(2), 195-206.

Lewis, J. \& Wood-Robinson, C. (2000). Genes, chromosomes, cell division and inheritance - do students see any relationship? International J ournal of Science Education 22, 177-195.

Lewis, J., Leach, J. \& Wood-Robinson, C. (2000). What's in a cell?-Young people's understanding of the genetic relationship between cells, within an individual. J ournal of Biological Education, 34(3), 129-132.

Mintzes, J., Wandersee, J., \& Novak, J. (2002). Teaching science for understanding: A human constructivist view. San Diego, USA: Academic Press.

Quinn, F., Pegg, J. \& Panizzon, D. (2009). First-year biology students' understanding of meiosis: an investigation using a structural theoretical framework. International J ournal of Science Education 31(10), 1279-1305.

Palmberg, I. (2005a). Arviointi ja arvostelu. I: V. Eloranta, E. Jeronen\& I. Palmberg (red.) Biologia eläväksi. Biologian didaktiikka, s. 217-237. Jyväskylä: PS-Kustannus.

Palmberg, I. (2005b). Biologian opetusmuodot ja työtavat. I: V. Eloranta, E. Jeronen\& I. Palmberg (red.) Biologia eläväksi. Biologian didaktiikka, s. 93-16o. Jyväskylä: PS-Kustannus.

Rotbain. Y., Marbach-Ad, G. \& Stavy, R. (2005). Understanding molecular genetics through a drawing-based activity. J ournal of Biological Education 39(4), 174-178.

Rotbain, Y., Marbach-Ad, G. \& Stavy, R. (2006). Effect of bead and illustrations models on high school students' achievement in molecular genetics. J ournal of Research in Science Teaching 43(5), 500-529.

Rothhaar, R., Pittendrigh, B.R. \& Orvis, K.S. (2006). The Lego analogy model for teaching gene sequencing and biotechnology. J ournal of Biological Education 40(4), 166-171.

Saka, A., Cerrah, L., Akdeniz, A. \& Ayas, A. (2006). A cross-age study of understanding of three genetic concepts: How do they image the gene, DNA, and chromosome? J ournal of Science Education and Technology 15(2), 192-202.

dos Santos, V.C., Joaquim, L.M. \& El-Hani, C.N. (2012). Hybrid deterministic views about genes in biology textbooks: A key problem in genetics teaching. Science \& Education 21, 543-578.

Shaw, K. R. M., Horne, K. Van, Zhang, H. \& Boughman, J. (2008). Essay contest reveals misconceptions of high school students in genetics content. Genetics 178, 1157-1168. 
Spradling, A., Ganetsky, B., Hieter, P., Johnston, M., Olson, M., Orr-Weaver, T., Rossant, J., Sanchez, A. \& Waterson, R. (2006). New roles for model genetic organisms in understanding and treating humn diseases. Genetics 172, 2025-2032.

Stephen B. Witzig, S.B., Freyermuth, S.K., Siegel, M.A., Izci,K. \& Pires, J.C. (2013). Is DNA alive? A study of conceptual change through targeted instruction. Research of Science Education 43, 1361-1375.

Templin, A.T. \& Fetters, M.K. (2002a). Meselson-Stahl experimental simulation using Lego ${ }^{\mathrm{TM}}$ building blocks. The American Biology Teacher 64, 613-619.

Templin, A.T. \& Fetters, M.K. (2002a). A working model of protein synthesis using Lego ${ }^{\mathrm{TM}}$ building blocks. The American Biology Teacher 64, 673-678.

Tsui, C. Y. \& Treagust, D. (2010). Evaluating secondary students' scientific reasoning in genetics using a two-tier diagnostic instrument. International J ournal of Science Education, 32(8), 10731098.

Van der Zande, P., Akkerman, S.F., Brekelmans, M., Waarlo, A.J. \& Vermunt, J.D. (2012). Expertise for teaching biology situated in the context of genetic testing. International J ournal of Science Education 34(11), 1741-1767.

Verhoeff, R., Waarlo, A.J. \& Boersma. K. (2007). Systems modelling and the development of coherent understanding of cell biology. International J ournal of Science Education 30(4), 543 -568.

Williams, M., Debarger, A.H., Montgomery, B., Zhou, X. \& Tate, E. 2012. Exploring middle school students' conceptions of the relationship between genetic inheritance and cell division. Science Education 96(1), 78-103.

Yip, D.Y. (1998). Children's misconceptions on reproduction and implications for teaching. J ournal of Biological Education 33, 21-27.

Zohar, A., \& Nemet, F. (2002). Fostering students' knowledge and argumentation skills through dilemmas in human genetics. International J ournal of Research in Science Teaching 39(1), 3562. 